\title{
Universitat i societat del canvi amb elements explicatius d'una crisi institucional
}

\author{
Bartomeu Mulet-Trobat \\ Universitat de les Illes Balears. Espanya. https://orcid.org/0000-0002-0182-295X \\ Correu per a la correspondència: tom200@hotmail.es
}

Article de recerca. Rebut: 27/07/2021. Acceptat: 21/10/2021. Publicació avançada: 19/11/2021. Publicació: 03/01/2022.

\begin{abstract}
Resum
INTRODUCCIÓ. Enfront dels plantejaments de modernització de la universitat espanyola sovint hi ha diversos qüestionaments, especialment si tenim present l'evolució organitzativa i burocràtica de les estructures universitàries, incloent-hi les acadèmiques, que dificulten, per no dir que impossibiliten, un canvi en la línia que es proposa en el marc de la Unió Europea (espai europeu d'educació superior) i de la societat del coneixement o de la informació en el context de la globalització capitalista i del neoliberalisme.
\end{abstract}

MÈTODE. Es tracta d'un treball de reflexió sociològica teòrica a partir d'autors com Francisco Fernández Palomares, Buenaventura de Santos Sousa, Jaume Carbonell, Henry Giroux, Sheila Slaughter, Gary Rhoades o Derek Bok, que aporten un sentit crític sobre l'educació superior, així com a partir del web del Ministeri d'Universitats. El treball comprèn també una reflexió sobre el funcionament real de la universitat amb les seves contradiccions en el context d'una societat aparentment i formalment democràtica.

RESULTATS i DISCUSSIÓ. Els resultats expliquen per què es pot parlar de la crisi del sistema universitari a l'Estat espanyol i posen de manifest, almenys parcialment, els dubtes que es generen en el coneixement, la cultura, la docència i la investigació que es duen a terme a la universitat.

Paraules clau

Crisi, Universitat, Societat del canvi, Capitalisme, Neoliberalisme, Democràcia.

\section{Referència recomanada}

Mulet-Trobat, B. (2022). Universitat i societat del canvi amb elements explicatius d'una crisi institucional. REIRE Revista d'Innovació $i$

Recerca en Educació, 15(1), 1-18. https://doi.org/10.1344/reire.35947

(C) 2021 L'autor. Aquest article és d'accés obert subjecte a la llicència de Reconeixement 4.0 Internacional Creative Commons, la qual permet utilitzar, distribuir i reproduir per qualsevol mitjà sense restriccions sempre i quan se citi adequadament l'obra original. Per veure una còpia de la llicència, visiteu 


\section{Título (castellano)}

Universidad y sociedad del cambio con elementos explicativos de una crisis institucional

\section{Resumen}

INTRODUCCIÓN. Frente a los planteamientos de modernización de la universidad española a menudo se encuentran varios cuestionamientos, especialmente si tenemos presente la evolución organizativa y burocrática de las estructuras universitarias, incluyendo las académicas, que dificultan, por no decir que imposibilitan, un cambio en la línea que se propone en el marco de la Unión Europea (Espacio Europeo de Educación Superior) y de la sociedad del conocimiento o de la información en el contexto de la globalización capitalista y del neoliberalismo.

MÉTODO. Se trata de un trabajo de reflexión sociológica teórica a partir de autores como Francisco Fernández Palomares, Buenaventura de Santos Sousa, Jaume Carbonell, Henry Giroux, Sheila Slaughter, Gary Rhoades o Derek Bok, que aportan un sentido crítico sobre la educación superior, así como a partir de la web del Ministerio de Universidades. El trabajo comprende también una reflexión sobre el funcionamiento real de la universidad con sus contradicciones en el contexto de una sociedad aparente y formalmente democrática.

RESULTADOS Y DISCUSIÓN. Los resultados explican por qué se puede hablar de la crisis del sistema universitario en el Estado español, poniendo de manifiesto, al menos parcialmente, las dudas que se generan en el conocimiento, la cultura, la docencia y la investigación que se llevan a cabo en la universidad.

\section{Palabras clave}

Crisis, Universidad, Sociedad del cambio, Capitalismo, Neoliberalismo, Democracia.

\section{Title (English)}

University and society in a time of change: elements that explain the institutional crisis

\section{Abstract}

INTRODUCTION. The plans for modernizing the Spanish university face many challenges. The organizational and bureaucratic evolution of university structures, including academic structures, present often insurmountable obstacles to the reforms proposed within the framework of the EU's European Higher Education Area and the knowledge and information society, in the context of global capitalism and neoliberalism.

METHOD. This study is a theoretical sociological reflection by authors such as Francisco Fernández Palomares, Buenaventura De Santos Sousa, Jaume Carbonell, Henry Giroux, Sheila Slaughter, Gary Rhoades and Derek Bok, who provide critical reflections on Higher Education as well as on the Web of the Ministry of Universities. The study also includes a discussion of the real functioning of the University, with all its contradictions, in the context of an apparently democratic society.

RESULTS and DISCUSSION. The results explain why it is justifiable to speak of a crisis in the university system in Spain, highlighting, at least partially, the doubts that arise in knowledge, culture, teaching and research carried out at the University.

\section{Keywords}

Crisis, University, Society of change, Capitalism, Neoliberalism, Democracy. 


\section{Introducció}

Actualment i des dels inicis del segle XXI, a Europa es produeix una pressió pel canvi de la universitat impulsat formalment des del Pla Bolonya (1999), en el context de l'anomenat espai europeu d'educació superior (EEES), que ha legitimat la política universitària de les darreres dècades (Fernández Palomares, 2006, p. 21). ${ }^{1}$ Tanmateix, en teoria les universitats són un element significatiu de transformació social i un bé públic per a la societat, encara que sovint es percebi que van cap a un model mercantilista i tecnocibernètic salvaguardador de l'ordre establert. En aquest mateix sentit, en el preàmbul del comunicat final de la Conferència Mundial d'Educació Superior del 2009 es recorda, de manera políticament correcta, que l'educació superior és un bé públic i imperatiu estratègic per a tots els nivells educatius i és assumida per tots els governs tal com s'assenyala en la Declaració Universal dels Drets Humans: «Cal que [...] s'obri a tothom l'accés als estudis superiors amb plena igualtat per a tots amb atenció al mèrit de cadascú (article 26, paràgraf 1)» (CMES, 2009).

En la planificació universitària cal que la responsabilitat social de l'educació superior es tingui en compte segons el desenvolupament de sis punts bàsics, que se sintetitzen seguidament (CMES, 2009):

1. L'educació superior com a bé públic és responsabilitat de tots els actors involucrats, especialment els governs.

2. Davant la complexitat dels desafiaments globals presents i futurs, l'educació superior té la responsabilitat social de millorar la nostra comprensió de qüestions que presentin múltiples arestes, amb dimensions socials, econòmiques, científiques i culturals per respondre-hi amb habilitat.

3. Les institucions d'educació superior, a través de les seves funcions de docència, recerca i extensió, desenvolupades en contextos d'autonomia institucional i llibertat acadèmica, haurien d'incrementar la seva mirada interdisciplinària i promoure el pensament crític i la ciutadania activa i contribuir a l'assoliment del desenvolupament sostenible, la pau, el benestar i els drets humans, incloent-hi la igualtat de gènere.

4. L'educació superior ha de proveir i contribuir a l'educació de ciutadans ètics, compromesos amb la construcció de la pau, la defensa dels drets humans i els valors de la democràcia.

5. Hi ha una necessitat de més informació, obertura i transparència en relació amb les diferents missions i amb l'acompliment de les institucions individuals.

6. L'autonomia és un requisit necessari per complir les missions institucionals amb qualitat, pertinença, eficiència, transparència i responsabilitat social.

Així i tot, aquests punts es poden matisar. Per exemple, en el punt 1 es planteja una educació superior com a servei públic, la qual cosa no vol dir, però, que sigui una conquesta assolida, ja que es produeix una privatització encoberta pels interessos de la comercialització (Bok, 2011) o mercantilització institucionalitzada regulada pel govern central. Sobre el punt 2, l'educació superior té la responsabilitat d'aplicar els coneixements en una societat globalitzada. En relació amb el punt 3, encara que en el paper formalment englobi «funcions de docència, recerca i extensió, desenvolupades en contextos d'autonomia institucional i llibertat acadèmica», aquestes en realitat són una quimera per impossibilitar la construcció de la defensa dels drets humans i del pensament crític coherent; fins i tot la desigualtat de gènere es veu afectada per una estructura muntada amb els interessos dels homes de poder universitari. En el punt 4 es diu que l'educació superior ha de contribuir a un món pacifista i democràtic i a la defensa dels drets humans, però això està per veure, ja que la realitat institucional és bastant burocràtica, jeràrquica i no gaire democràtica. En el que es refereix al punt 6 , quan es parla d' «eficiència» en realitat aquesta

\footnotetext{
${ }^{1}$ De totes maneres, estem a l'espera del projecte legislatiu estrella del 2021 del Ministeri d'Universitats, que ha comunicat que se'n presentaran les línies generals de cara a aquest any.
} 
és confon amb una preocupació per l'eficàcia, per simplificar les accions complexes, per fer encaixar els objectius en les programacions establertes amb anterioritat, amb el mínim de personal qualificat i prioritzant la quantitat per davant de la qualitat i la tecnificació i la digitalització per davant de la presencialitat.

Tot i això, es produeixen insuficiències i contradiccions a l'hora d'assumir aquests plantejaments, perquè o bé es dissimulen altres interessos (economicisme, mercantilisme, privatització, consumisme, tecnificació...), no sempre manifests, o bé es produeixen disfuncionalitats, que a vegades no són transparents, amb manca de professorat, discriminacions i falta de finançament públic.

També es diu que la universitat del segle XXI segueix generant processos per assegurar la producció de coneixements i la seva extensió a grups més amplis. Hipotèticament, la seva missió està en transformació permanent, la seva visió en constant efervescència i el seu lideratge -en el camp de l'elaboració i transmissió del coneixement- requereix una nova sensibilitat pels canvis socials. El context d'aquesta nova concepció de les universitats es fonamenta en la formació basada en competències, en la idea que aquest concepte involucra una concepció de la manera de producció i transmissió dels coneixements, una concepció de la relació de les universitats amb la societat, de com concebem la missió i la visió institucional, de les pràctiques concretes de l'ensenyament, de la formació i avaluació dels docents, de l'acompliment dels estudiants o del disseny dels programes d'incorporació de les noves tecnologies, entre d'altres (Proyecto Tuning, 2008).

En les dinàmiques universitàries se silencien moltes de les qüestions que succeeixen en el dia a dia i que van més enllà de la crítica mediàtica; no transcendeixen d'alguna tertúlia de cafè o despatx. Subsisteixen elements clàssics de les seves disfuncions institucionals i organitzatives, afegint nous elements de tipus autoritari i conservador. Persisteixen elements com l'endollisme, el corporativisme, la pressió dels grups d'interès, el tràfic d'influències o les discriminacions acadèmiques, en sentit microsociològic i macrosociològic, en el context capitalista global, que allunyen la institució de la seva deguda democratització. ${ }^{2}$

Una de les qüestions bàsiques és saber detectar i comprendre les situacions més ajustades a la realitat institucional, amb les corresponents matisacions segons les característiques contextuals concretes dels exemples d'universitats analitzades, tant en el marc general macrosociològic com en el microsociològic, per les seves característiques particulars com a organització instituïda en l'àmbit de la funció de l'educació universitària. Algunes de les qüestions que es plantegen tenen a veure amb el fet que ens trobem davant la desdemocratització de la universitat sense haver arribat a la democratització de les seves estructures com a institució, perquè està al servei del neoliberalisme conservador i del capitalisme tecnològic.

La crisi de la universitat es veu accentuada amb la crisi de l'estat del benestar i la retallada de pressupost a les universitats públiques imposada pel Govern de l'Estat espanyol: ens porta a pensar que el tema no només arriba a les universitats públiques de més pes, sinó al conjunt del sistema institucional universitari espanyol.

Metodològicament, aquest article és un treball de reflexió sociològica teòrica que ha estat elaborat a partir d'autors com Francisco Fernández Palomares, Buenaventura de Santos Sousa, Jaume Carbonell, Henry Giroux, Sheila Slaughter, Gary Rhoades o Derek Bok, que aporten un sentit crític sobre l'educació superior universitària, i que compta també amb informació recollida del web del Ministeri d'Universitats. El treball comprèn així mateix una reflexió sobre el funcionament real de la universitat, amb les seves problemàtiques complexes en el context d'una societat aparentment i formalment democràtica i d'un estat del benestar en crisi.

\footnotetext{
${ }^{2}$ Com afirma De Sousa Santos (2006), cal impulsar una reforma democràtica i emancipadora a escala mundial i així superar l'immobilisme jeràrquic que la caracteritza.
} 


\section{Universitat i societat del canvi capitalista afavoridor d'un conservadorisme mercantilista}

Sovint es diu que la universitat ha de ser el motor que ha de transformar la societat, però en realitat es planteja una universitat dependent dels interessos d'una societat corporativa i economicista, de cultura classista, i no en el sentit de motor global de canvi social en igualtat d'oportunitats ni com un bé públic. Es potencia el creixement de la institució en una societat desenvolupista i mercantilista, facilitadora d'una mentalitat poc crítica amb l'estructuració del sistema universitari vigent, a remolc de la societat globalitzada i capitalista, ${ }^{3}$ facilitadora d'una hibridació de la universitat en un estat neoliberal (Slaughter i Rhoades, 2004, p. 20-22).

Algunes de les característiques de la societat del canvi - una societat canviant, molt àmplia, complexa $\mathrm{i}$ caracteritzada per la modernitat tardana $-{ }^{4}$ es poden resumir de la manera següent:

- Societat líquida, fluïdificada, impulsora de canvis accelerats i efímers, fins i tot fràgils, vulnerables, en què qualsevol trama de nexes socials, especialment una xarxa amb base territorial, resulta un obstacle que ha de ser eliminat pels poders globals, com a força de desterritorialització (Bauman, 2004, p. 19-20).

- Fragmentació de les classes socials mitges i baixes, amb la consegüent diversificació de la seva situació social i accentuació de la seva feblesa i inseguretat. Es produeix una polarització dels extrems de la piràmide i creix la desigualtat entre aquests. Com diu Bauman (2014), els rics cada vegada són més rics i els pobres cada vegada més pobres, tendència que afavoreix l'opulència d'uns pocs i la perpetuació de les desigualtats socials.

- Mediatització de masses de la societat, en què la televisió i Internet són els grans difusors de la cultura consumista i de la manipulació ideològica.

- Ideologia de l'eficàcia: apoteosi instrumental i tecnològica sobre principis pedagògics de denúncia de les desigualtats socials, ideologia que afavoreix la macdonaldització educativa (Ritzer, 1996).

- Redefinició ideològica, desmobilització justificadora dels canvis en l'estructura social com un element més del control social del conservadorisme postmodern, amb un grau de tergiversació ideològica molt significatiu.

- Naixement de nous protagonismes i moviments socials, com la immigració. També l'ecologisme, el nacionalisme $\mathrm{i}$ el feminisme ajuden a desfer els elements desmobilitzadors, $\mathrm{i}$ fins $\mathrm{i}$ tot ajuden a desemmascarar reaccionaris en la societat actual i aporten noves categories a l'estructura social (classeestatus, raça-ètnia i sexe-gènere).

- Paper condicionador radical de la globalització, no només en sentit econòmic, sinó també polític, social i cultural, en el qual es produeix un intent d'estandardització dels sistemes educatius per assolir el mercantilisme cultural vigent. Nova migració i canvis demogràfics, desterritorialització del capital i noves formes d'exclusió social, etnonacionalisme, atur i precarietat.

- Reducció de les despeses socials, entre les quals les d'educació, com a repercussions de les crisis econòmiques dels anys setanta i del 2008, presents ininterrompudament. Es redefineix l'individualisme egoista i competitiu.

\footnotetext{
${ }^{3}$ És a dir, no ens dona pautes per superar una societat capitalista en crisi en què persisteix l'explotació, el mercantilisme i la tecnificació davant la necessitat d'encarar una educació diferent no individualista ni consumista i respectuosa amb el medi ambient (Sábato, 2021, p. 72-78).

${ }^{4}$ El concepte de modernitat tardana en un sentit semblant al que refereixen Anthony Giddens (1993, p. 52-58) o Zygmunt Bauman (2004): més que postmodernitat estem en una fase tardana de la modernitat, perquè aquesta no es pot donar per conclosa i es troba altament condicionada per la globalització capitalista.
} 
- Qüestionament de l'estat del benestar, evidència del seu afebliment, triomf de la ideologia neoliberal: predomini de criteris econòmics sobre criteris polítics que debilita l'estat del benestar en benefici del capitalisme global.

- Riscos, com el desenvolupisme desenfrenat, que provoca la necessitat de defensar la naturalesa, amb el risc de parèixer conservador i poc amant del progrés humà. Sigui socialment o culturalment, però, aquests riscos universalitzats no comporten la garantia de la preservació de les cultures conegudes ni de les dominants, ni tampoc de la manera de vida en el planeta (Samper, 1998, p. 71-72).

Cap d'aquests conceptes és neutral en realitat, especialment en un món hiperburocratitzat i corporativista, on quasi tot es mesura amb paràmetres econòmics i segons una política que afavoreix la desmobilització i la passivitat ciutadanes.

Per altra banda, les diferents maneres de relació universitat-societat han estat influenciades per les funcions inherents a la universitat: docència (professionalització), investigació (producció del coneixement) i extensió (servei social) (Malagón Plata, 2009a, p. 88; 2009b). Per bé que sovint aquestes funcions han tingut i tenen limitacions, s'han transformat, encara que sigui relativament, forçades per la realitat.

Ens ha tocat viure una època en què la qüestió pública està sota el signe de l'assalt, davant la concentració de poder. L'educació superior està assetjada, com els docents, estudiants i sindicats. La democràcia penja d'un fil. Però hi ha possibilitat de resistència, i cal que els educadors s'hi situïn al capdavant. Henry A. Giroux (2016, p. 21) assenyala algunes accions que els educadors podrien dur a terme per posar l'educació superior al servei de la democràcia i no al servei dels agents privatitzadors i de la desregulació, la comercialització i la concentració de poder.

La institució universitària es troba en un agut procés de transformació, tant a Europa, atès l'avenç en el procés de reforma conegut com a Procés de Bolonya, com en altres parts del món, especialment a Amèrica Llatina $\mathrm{i}$ Àfrica, on els sectors neoliberals pressionen perquè l'escàs finançament se centri en la formació primària $i$ secundària, deixant al marge la universitat (Galceran Huguet, 2013, p. 155).

Per exemple, l'educació superior com a mercaderia educativa, segons De Sousa, és un objectiu a llarg termini necessari per a la transnacionalització del mercat, ja en marxa des de l'any 2000: la transnacionalització neoliberal de la universitat passa sota el patrocini de l'Organització Mundial del Comerç en l'àmbit de l'Acord General sobre el Comerç de Serveis (GATS) i la universitat es comercialitza (Slaughter i Rhoades, 2004, p. 21, 62-63). L'educació és un dels dotze serveis compresos en aquest acord, l'objectiu del qual és promoure la liberalització del comerç de serveis a través de l'eliminació, progressiva i sistemàtica, de les barreres comercials. El GATS es va transformar en un dels temes més polèmics de l'educació superior (De Sousa Santos, 2006, p. 36-37).

Tot això provoca que els seus defensors considerin ampliar i diversificar l'oferta d'educació i les maneres de transmetre-la, de tal manera que es fa possible combinar guany econòmic amb un més ampli accés a la universitat. Aquesta oportunitat es basa en les condicions següents: fort creixement del mercat educatiu en els darrers anys, creixement tot just obstaculitzat per les barreres nacionals, difusió de mitjans electrònics d'ensenyament i aprenentatge, necessitats de mà d'obra qualificada que no són encara satisfetes, augment de la mobilitat d'estudiants, docents i programes i incapacitat financera dels governs per satisfer la creixent demanda d'educació superior. Aquest és el potencial de mercat que el GATS planeja assolir el potencial de mercat mitjançant l'eliminació de les barreres al comerç en aquesta àrea.

En definitiva, pot ser que es tracti també de criteris privats, de "gestió privada de la cosa pública» en el context neoliberal, com indica Albert Corominas (2016, par. 7): 
Quant a les universitats, tot i que gaudeixen d'un marge molt ampli en llur gestió (a diferència dels ajuntaments, per exemple, no estan subjectes a intervenció i reten comptes a posteriori) sovint han considerat convenient, en aquest ambient de desprestigi de la cosa pública i d'exalçament de la privada, constituir societats o fundacions, en particular per a gestionar la formació permanent o, en alguns casos, els contractes de la universitat amb entitats públiques i privades. Fins i tot és present el cas de fundacions d'universitats públiques que han creat centres docents, de dret privat, adscrits a les mateixes universitats, en els quals s'imparteixen títols oficials a preus molt superiors als públics.

Les Universitats es regeixen per normes menys estrictes que les de les administracions públiques $\mathrm{i}$, en tenir personalitat jurídica, objectius i òrgans de govern propis, poden generar afers impropis d'una universitat pública.

\section{Universitat i societat del coneixement}

El discurs es repeteix. Al segle $X X$ entrem en una nova època d'alternatives amb grans avenços científics $i$ tecnològics i amb coneixements sense precedents, però sense la preparació adequada ni suficient per resoldre els desafiaments que s'aproximen, que ja són aquí, en els quals la universitat hauria d'aportar llum, com a cim del sistema educatiu, al desenvolupament de les societats corresponents (Botkin et al., 1979).

La tecnificació i la digitalització són elements que cal tenir molt presents avui en dia en els plantejaments científics i educatius, en concret en l'àmbit de la universitat i la investigació. Pel que fa a la digitalització, diu Jaume Carbonell (2020, par. 5):

En el nostre entorn coneixem alguns antecedents d'aprenentatge virtual en línia com la UNED (Universidad Nacional de Educación a Distancia) o la UOC (Universitat Oberta de Calalunya), però les noves universitats - la majoria privades - s'apunten a aquesta modalitat, i moltes altres, públiques o privades, realcen aquests dies les excel-lències d'aquest nou aprenentatge en línia, assegurant fins i tot que millora el rendiment estudiantil. Per això proposen que es combini el sistema mixt o híbrid, que combina presencialitat amb virtualitat. Pot ser una situació transitòria per a més endavant donar l'estocada final, amb la desaparició definitiva dels estudiants de les aules i la reconversió de la universitat en una mera seu virtual.

Ara, per a la universitat del segle XXI el concepte de societat del coneixement sembla ser el seu aliat per recuperar un protagonisme qüestionat, especialment per l'anomenada desconnexió amb la societat, la qual cosa significa que la universitat com a institució, i en menor mesura el sistema educatiu en general, s'analitzen sovint des de la perspectiva de les carreres tècniques, ciències i enginyeria sobretot, oblidant els altres camps del coneixement com les humanitats o les ciències socials. Així es manifesta expressament quan es tracta dels tan anomenats rànquings de les universitats, en especial el conegut com a l'Academic Ranking of World Universities. A l'Estat espanyol no $s$ 'ha sentit pràcticament cap referència al fet que aquest rànquing no inclou els estudis en ciències socials, amb l'excepció de l'economia. La raó seria que les ciències socials no disposen d'instruments de mesura de la producció científica homologables i homogenis internacionalment. La resposta és que les ciències socials no importen (Lasagabaster, 2013). Les ciències socials i humanes no acaben d'encaixar en la "globalització» neoliberal, en aquesta visió de la societat del coneixement tecnocràtica i tecnològica.

Com assenyala De Pablos (2010, p. 6), es produeixen nous reptes i compromisos que les institucions universitàries afronten davant l'anomenada societat del coneixement. Aquests reptes impliquen canvis significatius en els models d'ensenyament i la incorporació de les tecnologies de la informació i la comunicació. En el món actual, on s'ha assumit la necessitat de la formació al llarg de la vida i les tecnologies han passat a tenir un paper rellevant, la universitat està abocada a replantejar-se els seus objectius davant les demandes creixents de les societats i les noves pautes socioculturals. Els canvis exigits al voltant de l'educació superior recolzen en la necessitat social 
d'establir la seva rendibilitat científica i econòmica. En aquest context, la incorporació de nous formats, com el que implica la incorporació del concepte de competència, ha pres molta força. En aquest text, a partir de les referències aportades pel projecte DeSeCo (Definition and Selection of Competencies) es defineix el concepte de competència com a element referencial d'alguns dels canvis que s'estan produint en l'educació superior. S'aprofundeix en la idea de formació en competències informacionals; el sentit s'analitza en aquesta aportació. Aquestes es plantegen com un avenç respecte a les competències informàtiques (instrumentals) i queden vinculades a processos més complexos, lligats a la construcció de coneixement.

Els canvis socials i culturals actuals, en molts casos estretament relacionats amb la presència de les noves tecnologies de la informació, tenen com a conseqüència un impacte significatiu no només en la producció de béns i serveis, sinó en el conjunt de les interrelacions socials (De Pablos, 2010, p. 7).

És clar que aquests canvis a la universitat van bastant a remolc dels canvis a la societat, ja que en un context mundialitzador com l'actual, caracteritzat per una creixent globalització i una transformació accelerada, el paradigma tradicional o clàssic, com diria Miguel Casas (2005, p. 2), no resulta oportú ni coherent amb les noves realitats i demandes socioculturals i científiques, actuals i futures. De totes maneres, es produeix una dinàmica canviant a la universitat a conseqüència de l’anomenada era digital.

Els plantejaments i les idees que dirigeixen l'expansió futura del mercat educatiu, segons De Sousa Santos (2006, p. 52), són:

1. En viure en una societat de la informació, la gestió, la qualitat i la velocitat de la informació són essencials per a la competitivitat econòmica. La mà d'obra cal que sigui més qualificada, les tecnologies d'informació i comunicació tenen característiques que no sols contribueixen a l'augment de la productivitat i l'educació assumeix un lloc preeminent.

2. L'economia fonamentada en el coneixement exigeix capital humà com a condició de creativitat en l'ús de la informació, augment de l'eficiència en la economia de serveis i més capacitat per transferir capacitats cognitives.

3. Segons aquests plantejaments, les universitats han d'estar al servei d'aquestes dues idees mestres (societat de la informació i economia fonamentada en el coneixement), per això s'han de transformar mitjançant la tecnologia de la informació i de la comunicació i mitjançant els nous tipus de gestió i de relació entre els treballadors del coneixement i entre aquests i els usuaris o consumidors.

4. Això no és possible si es manté el paradigma institucional i polític pedagògic que domina a les universitats públiques. Cal que les relacions entre els públics rellevants siguin relacions mercantils; que la eficiència, la qualitat i la responsabilitat educatives siguin definides en termes de mercat; que es generalitzi en les relacions professor-alumne la mediació tecnològica; que la universitat s'obri -que es torni vulnerablea les pressions dels clients; que la competència entre "els operaris de la ensenyança» sigui l'estímul per a la flexibilitat i l'adaptabilitat a les expectatives dels ocupadors; que hi hagi selectivitat en la cerca dels nínxols de consum (reclutament d'estudiants) amb un retorn sobre el capital invertit més alt.

5. L'actual paradigma institucional de la universitat ha estat substituït per un paradigma empresarial del qual depenen tant les universitats públiques com les privades, i el mercat educatiu en què aquestes han d'intervenir ha de ser dissenyat globalment per poder maximitzar la seva rendibilitat. El benefici (concessió, privilegi) donat a les universitats privades es tradueix en una més fàcil adaptació d'aquestes a les noves condicions i imperatius.

Tot aquest protocol són orientacions per a la reforma de l'educació proposada pel Banc Mundial i per a la reconversió d'aquest en banc del coneixement (De Sousa, 2006, p. 33-34). Aquestes són qüestions a les quals cal 
plantejar una alternativa a la globalització hegemònica per un món més democràtic i igualitari (De Sousa, 2006, p. 52).

La imposició d'un model d'accountability, de rendició de comptes segons uns criteris estàndard per a totes les disciplines i per a totes les persones, lluny de l'objectivitat i l'equitat preteses, condueix - al nostre entendre- a una precarització de la relació laboral i vital que implica fer ciència i divulgar-la a través de la docència (Obiol i Villar, 2017, p. 37). L'extensió del model de l'accountability impulsa un ritme accelerat a l'hora de planificar la investigació, d'escriure i de presentar resultats, com també a l'hora de canalitzar i transmetre aquesta recerca en la docència. (Obiol i Villar, 2016, p. 38).

\section{Universitat i crisi de l'estat del benestar i del neoliberalisme postindustrial}

L'estat del benestar pateix una crisi bastant evident i es veu desbordat per les exigències socioeconòmiques, en què les conquestes assolides en matèria de benestar social superen les possibilitats reals que tenen els estats nació actuals de les societats desenvolupades.

Per a Carlos Gómez Bahillo (2001), la crisi de l'estat del benestar - que comença a produir-se en les societats desenvolupades a conseqüència de la globalització i la submissió de les polítiques econòmiques, monetàries, laborals i socials de cada país a les exigències dels grans blocs politicoeconòmics - ha suposat una pèrdua de l'autonomia de l'estat en el disseny de la seva política econòmica i dels seus sistemes de protecció social. La política prioritària de generació d'ocupació, que ha constituït l'eix central de les polítiques de benestar fins a mitjans dels anys setanta, es veu supeditada a les exigències monetàries i al funcionament del lliure mercat, que com a resultat del desenvolupament de la tecnologia de la informació ha adquirit una dimensió sense límits.

El neoliberalisme, les privatitzacions o la intervenció de l'estat a favor dels interessos privats i capitalistes són pressions que han fet posar en dubte les possibilitats de l'estat del benestar, que en principi es considerava un element democratitzador per a les societats occidentals. Pep Taberner parla d'un liberalisme social que qualifiquem d'estat del benestar, caracteritzat per una més gran atenció assistencial i protecció social, per donar possibilitats a les classes baixes, amb reformes comprensives com és el cas de l'escola comprensiva o l'ensenyament obligatori de franc per a totes les capes de població, però, tanmateix, continuen els desavantatges per a les classes treballadores (Taberner, 1999, p. 287-288).

En aquest sentit, Giroux (2015, p. 17) considera que el neoliberalisme, en el context del capitalisme, està lligat a la privatització dels serveis públics, i que com a forma de pedagogia pública i política cultural el neoliberalisme defineix totes les dimensions de la vida en termes de racionalitat de mercat. És així que el neoliberalisme, segons Giroux, legitima una cultura de la crueltat, de competència ferotge, i lliura una guerra contra els valors i esferes públics que desafien la regla i la ideologia del capital. Debilita les bases democràtiques de la solidaritat, degrada la col·laboració i estripa totes les formes d'obligació social. Com assenyala Giroux (2016, p. 22), a poc a poc l'estat del benestar és desmantellat, s'allunya de la idea d'elaborar un pla social i es converteix i es transforma en un estat controlador, més preocupat per la seguretat individual que no pel benestar ni la responsabilitat socials.

Com diu Daniel Reyes-Lara: La universitat moderna ha estat intervinguda per la lògica empresarial. La intensificació de la comercialització de la producció representa una sèrie de nous reptes per a la generació del pensament crític. En aquest treball s'analitzen tals desafiaments des d'un punt de vista tecnològic, per ressaltar la manera en què operen les noves tècniques de poder en l'àmbit universitari. Es destaca el biomàrqueting com 
una tecnologia de govern postdisciplinari que assenyala un desplaçament dels objectius de poder, que passen del control dels nostres cossos (individu-població) al dels nostres intercanvis (indústria-pensament) (Reyes-Lara, 2015, p. 1).

En conseqüència, es planteja un credencialisme tecnocràtic que influeix en una burocratització organitzativa a la universitat. ${ }^{5}$ En nom de les eficàcies organitzativa i macdonalditzada s'amaguen intencions inconfessables de desdemocratització del coneixement jerarquitzat. La creixent burocratització organitzativa institucional afecta la democratització en sentit negatiu, en nom del creixement i desenvolupament de la societat canviant, canalitzada per la tecnologia i la informació, per poder esquivar la complexitat de la tasca i facilitar l'assoliment de la rendibilitat eminentment econòmica.

Aquest context és afavorit per la mentalització social rebuda des dels mitjans de comunicació social i les pressions dels grups més poderosos del capitalisme modern, les grans organitzacions. Amb aquesta situació és normal que les teories del capital humà i del credencialisme, que argumenten a favor de la rendibilitat de l'educació des d'un punt de vista economicista, es recuperin per justificar les polítiques educatives, en què l'eficàcia i el benestar es complementen amb el desenvolupisme i la tecnologia moderna.

Amb tot això estem davant una crisi institucional. Es pot dir que en aquests últims trenta anys, en la majoria dels països, la crisi institucional de la universitat ha estat provocada o induïda per la pèrdua de prioritat del bé públic universitari en les polítiques públiques i el conseqüent desfinançament i descapitalització de les universitats públiques, tot i que les causes i les conseqüències han variat de país a país (De Sousa, 2006, p. 22).

L'espai europeu d'educació superior (EEES), creat per diferents països de la Unió Europea, té per objectiu engegar un sistema en què sigui més fàcil l'equivalència entre les titulacions d'educació superior dels diferents estats. D'aquesta manera, es facilita la mobilitat, tant estudiantil com professional, dels ciutadans de la Unió Europea.

\section{Actors bàsics de la universitat (professorat i alumnat) i docència universitària}

A la Declaració Mundial sobre l'Educació Superior al Segle XXI (1998) es reconeix que els docents i els alumnes són els protagonistes principals de l'educació superior i que la funció de les institucions d'educació superior és formar els estudiants perquè esdevinguin ciutadans ben informats i profundament motivats, proveïts d'un sentit crític $\mathrm{i}$ capaços d'analitzar els problemes, cercar solucions per als problemes que es plantegin a la societat i assumir responsabilitats socials. Això implica que els mètodes pedagògics, els materials didàctics i els mètodes d'examen han de permetre l'exercici no només de la memòria sinó també de les facultats de comprensió i l'aptitud per a les tasques pràctiques i la creativitat. Per això s'assenyala explícitament que cal una revisió dels mètodes pedagògics vigents que traslladi l'èmfasi posat actualment en la transmissió del coneixement cap al procés de la seva generació. Així es permet que l'alumnat adquireixi els instruments per aprendre a conèixer, a conviure i a ser, a més d'aprendre a viure junts i a construir la societat del futur.

Els reptes que ha d'afrontar el docent es troben en relació directa amb la complexitat del seu rol, afegida al fet que l'aplicació de les noves tecnologies de la informació i la comunicació suposaran canvis en el model universitari d'ensenyament, en les funcions del professor, en la responsabilitat que la societat diposita en el docent i en la relació docent-alumne amb l'interès central d'estimular la qualitat de l'educació, fonamentalment en aquesta

\footnotetext{
${ }^{5}$ Malgrat la crisi del credencialisme que apuntava R. Collins a finals del segle xx (Collins, 1989, p. 214-219).
} 
època de canvis culturals, històrics i socials, que es perfilen com a determinants de l'esdevenir cultural, històric i social.

Hi ha una diversificació de categories de professorat i components de mà d'obra barata (professorat associat) molt jerarquitzada i desequilibrada. Des del punt de vista del poder acadèmic i la compensació econòmica, cal una reordenació universitària del professorat. Caldrà redefinir el seu paper en el marc organitzatiu de la institució (Musselin, 2013).

El tecnòcrata neoliberal no garanteix el que predica, en el sentit que l'avaluació es presenta com a neutral, tècnica i objectiva i avalada per la consecució de processos d'avaluació transparents, universals i eficaços (Amigot i Martínez, 2015), potser pel fet d'estar vinculada a la utilització de mitjans internàutics d'informació sobrecarregada i imprecisa. Tant és així que sol resultar ser una concepció utilitarista a favor d'un rendiment limitat als interessos sectaris, quantificadors i arbitraris del poder acadèmic de cada estat nació, que debilita polítiques intencionalment afavoridores de la igualtat d'oportunitats en maniobres del mercat insolidari amb els estaments i capes de població més desfavorides, fins i tot en el si de les mateixes estructures del sistema educatiu i investigador, de la universitat també.

La crisi social que viu el capitalisme neoliberal comporta problemes de precarietat i atur que repercuteixen en la formació de professionals a la universitat, i fins i tot, aprofitant els temps de canvi del Pla Bolonya, pretén redefinir el paper social de la universitat a favor d'un mercat de la ciència; per tant, l'acorrala per deixar la feina docent $\mathrm{i}$ investigadora totalment a mans del màrqueting i de la publicitat per al seu autofinançament.

Quant a la docència universitària, s'estén una certa inquietud donada la poca incidència que té la seva valoració dins la universitat mateixa i, en canvi, s'exigeix que la universitat s'actualitzi de cara a la societat amb noves dinàmiques i necessitats acadèmiques i professionals.

La universitat és una institució que tracta de la docència del coneixement, que caldria que fos científic $\mathrm{i}$ professional, a més de la tasca de recerca. La tasca docent és menys valorada que la recerca, que és la que origina el prestigi del docent, i l'una i l'altra s'avaluen per canals diferents. Això provoca desmotivació per dedicar-se a la tasca docent.

La universitat està molt condicionada pels plantejaments estatals en el cas específic de la formació inicial dels mestres emanats del poder central, fet que ha provocat que no s'adeqüin a les exigències de la societat actual, ni a les necessitats acadèmiques i professionals, i que no estiguin a l'altura que exigeixen els canvis socials i polítics.

Per exemple, a l'Estat espanyol, el professorat d'infantil i primària es forma seguint un mateix model, en què es cursen uns estudis de grau de 240 crèdits durant quatre anys. ${ }^{6} \mathrm{~A}$ la formació inicial de mestres d'educació infantil i primària també queda marcat el nombre mínim de crèdits que han de destinar a determinats continguts i al pràcticum. A banda d'això, la normativa deixa força marge quant a l'orientació metodològica i pedagògica de la

\footnotetext{
${ }^{6}$ Encara que cal assenyalar que aquest model és el més generalitzat, a França i Portugal segueixen el model consecutiu, i a Bulgària, Estònia, Irlanda, Polònia, Eslovènia i el Regne Unit es pot optar per l'un o per l'altre. El títol de grau, amb una durada d'entre quatre i cinc anys, és el que s'exigeix a la majoria de països. A la República Txeca, Alemanya, Àustria, Malta i Eslovènia, però, els professors d'infantil no necessiten cap titulació superior (Informe Eurydice, 2015, p. 30; 2020). El terme títol de grau (en alguns països, també títol professional) s'aplica per anomenar una titulació d'educació superior que s'aconsegueix en finalitzar una carrera universitària d'entre tres i sis anys, depenent de la universitat i del país en el qual s'imparteix. Equival al bachelor's degree anglosaxó. Immediatament després de l'obtenció del títol de grau es poden cursar estudis de postgrau (principalment màster, o mestratge, i doctorat). Els termes títol de grau, títol professional i simplement títol al-ludeixen també al document que es fa constar a l'obtenció del grau.
} 
formació i, especialment, a les condicions del model formatiu, com el pràcticum, el pes de la llengua estrangera, etc.

De totes maneres, tot això va a remolc de l'EEES, procés iniciat amb la Declaració de Bolonya, signada el juny del 1999, pels ministres d'educació superior de 29 estats europeus i que s'ha desenvolupat durant més d'una dècada. És un procés que ha posat i posa l'èmfasi en l'impuls de la integració dels estudis, mitjançant l'adopció d'una estructura comparable entre les titulacions a escala europea i una millora del conjunt de l'educació superior. Pretén afavorir l'enfortiment de la dimensió intel-lectual, cultural, social, científica i tecnològica d'Europa.

L'objectiu és afavorir un plantejament "professionalitzador», encara que condicionat per les exigències dels poders econòmics. Però estem davant la necessitat d'una docència crítica, i en una societat que es resisteix al conflicte cal possibilitar la universitat com un espai crític, on el diàleg i la defensa de la justícia social es torna més necessària. Com a part d'un discurs més ampli sobre excel-lència, equitat i democràcia, hem de defensar el paper distintiu dels docents universitaris en aquest permanent projecte pedagògic de modelar les racionalitats crítiques, a través de les quals es defineix l'acció i es produeixen la cultura i l'alfabetització cívica, juntament amb el suport a les condicions institucionals i relacions de poder que les fan possible (Giroux, 2016, p. 20).

L'era digital afecta cada vegada més les característiques de la docència universitària, tant en termes de docència com d'investigació. La digitalització ha repercutit en la gestió de la universitat, si no en la forma d'entendre la docència (Sancho et al., 2018, p. 35-40). S'han impulsat noves formes de transmissió de continguts mitjançant l'ordinador i noves tecnologies (PowerPoint, videoconferències o classes a distància, per exemple), acompanyades de noves formes de control de la docència. Si no et digitalitzes no existeixes, lògica que s'imposa en detriment de la presencialitat i les relacions humanes docents directes.

\section{Universitat i desigualtat de gènere}

Les desigualtats per raons de classe, gènere o ètnia són una de les causes principals dels desequilibris socials, econòmics, culturals i educatius induïts per la situació jeràrquica que ha provocat i provoca l'estructuració de la societat, especialment quan parlem de les societats avançades.

Al mateix temps, els avenços que es produeixen en la societat es troben molts entrebancs estructurals que no permeten aflorar les desigualtats vigents i desmantellar-les en pro d'una societat més igualitària.

Classe, gènere, ètnia: una història de desigualtats i exclusions socials. Dit d'una altra manera: discriminació per raons de classe, gènere o ètnia com a fet cultural, fenomen viscut segons la cultura en què es viu i no com a fenomen natural ineludible.

És veritat que, en el sistema educatiu, especialment l'escolar, s'han fet moltes passes endavant; també és cert que la cultura funcional del paper dels sexes en la societat encara incideix molt i el progrés queda una mica allunyat d'una igualació de papers i funcions dels gèneres.

La discriminació per raons de classe, gènere o ètnia persisteix unes vegades de manera manifesta i d'altres de manera més subtil. Aquí la podem plantejar com un element més de l'estratificació social, en el sentit que tant la classe social com la discriminació de la dona o la minorització o exclusió d’una ètnia són fruit de la jerarquització social i provoquen una situació de desigualtat social i educativa, almenys de sortida.

Tot i que l'escola es presenta sovint com una institució no discriminatòria per motius socials, la sociologia, per contra, la descriu com una institució que reprodueix o reflecteix les divisions socials preexistents, i més aviat és 
un mecanisme que contribueix a reproduir-les a escala social global. L'escola actual és un model pensat per a les classes i els grups socials més afavorits.

En aquests darrers anys entenem que la sociologia, en el camp de l'educació, és una de les matèries que més s'ha plantejat la qüestió de la igualtat d'oportunitats i d'educació i, per tant, segurament - almenys acadèmicamentés una de les que més legitimada està per parlar-ne, no tan sols en termes de classes socials, sinó d'ètnia i de gènere. S'ha considerat en especial el paper de la dona en l'educació i en la societat en general perquè molts dels aspectes de la discriminació de la dona es reflecteixen en el món de l'educació. Marina Subirats, C. Brulllet, Consuelo Flecha, i Sandra Acker com a autoritat internacional, són algunes de les autores que han sistematitzat l'estudi de la discriminació en l'educació i han fet reflexions sociològiques sobre el paper de la dona al sistema educatiu.

Per altra banda, com argumenta José Saturnino Martínez García (2007, p. 297), en parlar de classe social, gènere i desigualtat d'oportunitats educatives les classes socials continuen sent determinants per explicar l'assoliment educatiu de la població. Però aquesta qüestió cal observar-la en un context més enllà de l'escola, en la família i en el mercat de treball, així com en processos polítics més generals, com el moviment per la igualtat de drets entre homes i dones. En la família, les filles han deixat de ser tan necessàries en el treball a casa, a mesura que s'anaven experimentant canvis en la producció domèstica. Pel que fa al mercat de treball, ha estat clar l'augment de la participació femenina, que es pot atribuir a tres factors:

1. L' «alliberament» de mà d'obra del treball domèstic.

2. L'expansió del sector serveis de l'economia, amb un increment de les ocupacions de mitjana qualificació en aquest sector, com les administratives, tradicionalment ocupades per dones.

3. La pujada del nivell de vida, ja que cada vegada és més necessari el sou de tots dos cònjuges per mantenir la família.

Tant és així que, donada la combinació entre augment de la participació laboral femenina i desigualtat laboral entre homes i dones, manca invertir més en educació en elles, ja que el cost d'oportunitat d'estudiar per a les dones és menor i els beneficis, grans. Per a elles, aquest cost d'oportunitat és més baix perquè el seu salari esperat també ho és: a l'Estat espanyol, el diferencial d'atur és de gairebé el doble, i la diferència salarial que cal atribuir a la desigualtat de gènere, entorn del $20 \%$. Però els beneficis d'estudiar són elevats, perquè, com en el cas dels homes, a part de millorar la seva productivitat en el mercat de treball, també millora la productivitat del treball domèstic. L'educació és més important per a la mobilitat ascendent de les dones. Les dones hereten la riquesa de la família en forma de capital cultural. La societat patriarcal, encara que sovint queda silenciada, hi és present; les dones assumeixen la tasques de la llar $i$ tenen cura dels fills, mentre que els homes fan el treball «productiu» (Martínez García, 2007, p. 297-298).

Per altra banda, segons ens indica Imma Pastor a la conferència «Dones i ciència: repensant la ciència des de la perspectiva de gènere»,

només 1 de cada 5,5 dones titulades de la Universitat Rovira i Virgili arriba a ser catedràtica, mentre que la proporció en els homes és de 2,2. En el cas dels grups de recerca universitaris, només un $28 \%$ estan liderats per dones i només en un $30 \%$ dels projectes de recerca les responsables són investigadores. [...] De fet, les últimes dades de l'informe estatal sobre la igualtat de gènere en el món universitari evidencien que encara el $79 \%$ dels catedràtics a les universitats són homes i només un $21 \%$ dones. La mateixa desigualtat la trobem en els càrrecs de govern de les universitats, i fora de l'àmbit universitari en el mercat laboral i en les administracions públiques. 
Les causes de tot plegat van més enllà que les dones puguin tenir més dificultats que els homes a l'hora de compaginar la vida laboral i familiar. "Veiem que no es presenten a premis o que no participen en tants congressos perquè no les conviden tant com als homes, i això influeix en la seua visibilitat» [...]. També hi influeixen determinats estereotips com que no hi hagi pràcticament dones a les enginyeries. "Això també les col-loca en un mercat laboral diferent, amb sous molt més baixos» (Pastor, 2017, pàr. 13).

Les universitats, en el seu conjunt, no han superat la xacra històrica que ha suposat, en perspectiva de gènere, la desigualtat envers la dona, tal com s'indica a l'informe La perspectiva de gènere en docència i recerca a les universitats de la Xarxa Vives d'Universitats, que analitza centres dels Països Catalans. Segons aquest estudi, els graus que incorporen alguna assignatura específica en matèria de gènere són només el $17 \%$ dels que es fan a cada universitat, i la majoria de les assignatures (61 \%) són optatives. Això vol dir que la desigualtat per raons de sexe que persisteix a Catalunya, el País Valencià i les Illes Balears és moltes vegades silenciada o ignorada (Hakobyan i Solano, 2017).

Segons ens indica Imma Pastor, «les dones investigadores estan fent més hores de classe, i per tant tenen menys temps per investigar perquè tenen més càrrega docent» (Pastor, citada a Rubio, 2021). Apunta al fet que, de nou, hi ha una divisió sexual del treball que acaba posant-les a elles a fer funcionar els fonaments de la universitat, les classes, mentre que ells se centren en allò que els atorga mèrits personals. La conseqüència d'això és clara: per cada dona catedràtica hi ha quatre homes en la mateixa categoria. I Tània Verge afegeix: «En algunes disciplines això és gairebé inexplicable, ja que són branques molt feminitzades. No s'explica que tan sols hi hagi un $12 \%$ de dones catedràtiques en ciències polítiques i de l'administració, per exemple, o que no hi hagi ni una sola dona de medicina obstètrica» (Verge, citada a Rubio, 2021).

Si considerem els percentatges de dones investigadores, tal com els presenta l'INE (Institut Nacional d'Estadística) segons el sector en què participen, podem exemplificar una altra desigualtat vigent (vegeu la taula 1):

Taula 1

Desigualtat de les dones investigadores en l'educació superior a l'Estat espanyol en equivalència a jornada completa (EJC)

\begin{tabular}{lcrrrr}
\hline & 2019 & 2018 & 2017 & 2016 & 2015 \\
\hline Total & $\mathbf{3 9 , 9}$ & $\mathbf{3 8 , 8}$ & $\mathbf{3 8 , 8}$ & $\mathbf{3 9 , 1}$ & $\mathbf{3 9 , 0}$ \\
Empreses & 32,2 & 31,5 & 31,3 & 30,6 & 31,0 \\
Ensenyament superior & 42,7 & 41,7 & 41,6 & 42,9 & 42,5 \\
Administració pública & 49,9 & 48,4 & 47,9 & 47,6 & 46,8 \\
Institucions privades sense afany de lucre & 51,1 & 52,2 & 52,7 & 47,8 & 53,7 \\
& & & & & \\
\hline
\end{tabular}

Font: Estadística sobre activitats d'R+D. INE, Estadística I+D (2020).

Segons les dades del 2019, expressades per sectors en equivalència a jornada completa (EJC), la màxima representació femenina correspon al sector d'institucions privades sense ànim de lucre $(51,1 \%)$, i la mínima al sector d'empreses (32,2\%); a mig camí, observem que un 49,9\% de la població femenina investigadora treballava a l'Administració pública i un 42,7 \% a Ensenyament superior (INE, 2020). 
A Europa veiem que la presència de les dones en la majoria dels camps de la vida econòmica, social i política és cada vegada més àmplia, però segueix sent particularment escassa en la investigació científica i en el desenvolupament tecnològic. No hi ha participació plena i íntegra de les dones (INE, 2020).

\section{Conclusió}

Les contradiccions del capitalisme i de la democràcia també es reflecteixen en la universitat, encara que sigui de manera específica segons les característiques de la institució i la seva funció social: una barreja d'autoritarisme i democràcia formal o, fins i tot, anant més enllà, «una curiosa barreja entre dictadura i democràcia», com diria Rafael Feito (2006, p.67). Es produeix l'emmascarament capitalista de la democràcia, amb actuacions antidemocràtiques $\mathrm{i}$ classistes que encobreixen la seva jerarquització elitista i escassament transparent $\mathrm{i}$ burocràtica.

En conjunt, veiem que no existeix una visió democràtica de l'educació en general ni de l'educació superior en particular, ja que l'anàlisi de l'educació superior s'ha d'entendre en un context de profunda crisi de la democràcia, que té un impacte als Estats Units i a Europa des de la dècada dels setanta, juntament amb l'ascens del terrorisme d'estat en nom de la seguretat de les estructures d'estat i ciutadana, per exemple (Giroux, 2015, p. 18). El que s'ha vist és l'emergència d'un fonamentalisme del lliure mercat que destrueix, juntament amb el neoliberalisme i les polítiques de dretes, la democràcia (Giroux, 2015, p. 16). És un fenomen que, per altra banda, es pot aplicar també a les estructures de l'Estat espanyol en un sentit general, $i$ a les universitats en un sentit concret.

En el context de la globalització i de les tecnologies de la informació, l'ensenyament tradicional a poc a poc és substituït per la universitat en línia, i l'educació està a disposició de la majoria de la població (Giddens i Sutton, 2014, p. 1023-1024). La presencialitat queda en segon lloc en detriment de la relació directa, una tendència que forma part de la virtualitat generalitzada. La digitalització actua directament en les característiques de la concepció de la universitat, la seva gestió, investigació i docència. El context on la relació humana directa pot quedar reduïda a la mínima expressió.

A la universitat, a les rutines clàssiques se'ls afegeixen noves rutines derivades de la societat del canvi i del coneixement, de polítiques enfocades sota criteris utilitaristes i mimètics, a remolc dels plantejaments exigits per la dinàmica economicista de la globalització i els canvis. Aquest canvi actua contra l'estat del benestar i el posa en qüestió, desmantella la seva possible incidència en la igualtat d'oportunitats educatives i concep la universitat, l'últim graó del sistema educatiu, com un element més de selecció social i educativa, a més de conservar el seu elitisme clàssic.

\section{Referències}

Amigot, P., i Martínez, L. (2015). Procesos de subjetivación en el contexto neoliberal. El caso de la evaluación del profesorado y la investigación universitaria. Revista de la Asociación de Sociología de la Educación RASE, $8(2), 138-155$.

Bauman, Z. (2004). Modernidad líquida. Fondo de Cultura Económica. (Primera impressió 2003).

Bauman, Z. (2014). ¿La riqueza de unos pocos nos beneficia a todos? Paidós.

Bok, D. (2011). Universidades a la venta. La comercialización de la Educación Superior. Universitat de València. 
Botkin, J. W., Elmandjra, M., Malitza, M., i Corral, A. (1979). Aprender, horizonte sin límites. Informe al club de Roma. Santillana.

Carbonell, J. (2020, 14 de juny). Tres models escolars; tres maneres d'entendre l'educació (I). El diari de l'educació. https://diarieducacio.cat/tres-models-escolars-tres-maneres-dentendre-leducacio-i/

Casas, M. (2005). Nueva universidad ante la sociedad del conocimiento. Revista de Universidad y Sociedad del Conocimiento, 2, 1-17. http://dx.doi.org/10.7238/rusc.v2i2.252

CMES (2009). Las nuevas dinámicas de la educación superior y de la investigación para el cambio social y el desarrollo. Comunicado final. Perfiles educativos, 31(126), 119-126.

http://www.scielo.org.mx/scielo.php?script=sci_arttext\&pid=S0185-26982009000400008

Collins, R. (1989). La sociedad credencialista. Akal.

Corominas, A. (2016, 20 d'octubre). Vicis privats a les universitats públiques? El diari de l'educació. https://diarieducacio.cat/vicis-privats-a-les-universitats-publiques

De Pablos, J. (2010). Universidad y sociedad del conocimiento. Las competencias informacionales y digitales. Revista de universidad y sociedad del conocimiento, 2, 6-16. https://rusc.uoc.edu/rusc/ca/index.php/rusc/article/download/v7n2-de-pablos/977-1015-1-PB.pdf

De Sousa Santos, B. (2006). La universidad popular del siglo xxi. Fondo Editorial de la Facultad de Ciencias Sociales (Lima).

Feito, R. (2006). Docencia Universitaria. A: M. García Lastra, A. Calvo Salvador, J. M. Osoro Sierra i S. Rojas Pernia (coord.), Convergencia con Europa y cambio en la Universidad. XI Conferencia de Sociología de la Educación: Santander, 22, 23 i 24 de setembre de 2006, Germania (p. 49-73).

Fernández Palomares, F. (2006). Convergencia con Europa. Aspectos críticos. A: M. García Lastra, A. Calvo Salvador, J. M. Osoro Sierra y S. Rojas Pernia (coord.), Convergencia con Europa y cambio en la universidad. XI Conferencia de Sociología de la Educación: Santander, 22, 23 i 24 de setembre de 2006, Germania (p. 21-39).

Galceran Huguet, M. (2013). Entre la academia y el mercado. Las universidades en el contexto del capitalismo basado en el conocimiento. Athenea Digital, 13(1), 155-167.

https://dialnet.unirioja.es/servlet/articulo?codigo $=4165335$

Giddens, A. (1993). Consecuencias de la modernidad. Alianza.

Giddens, A., i Sutton, P. W. (2014). Sociología. Alianza.

Giroux, H. (2015). Democracia, educación superior y el espectro del autoritarismo. Revista EntramadosEducación y Sociedad, 2, 15-27.

Giroux, H. (2016). La educación superior y las políticas de ruptura. Revista Entramados- Educación y Sociedad, $3(3), 15-26$.

Gómez Bahillo, C. (2001). Globalización y crisis del estado de bienestar. 5campus.com, Sociología. http://www.5campus.com/leccion/globalcrisis 
Hakobyan, S., i Solano, A. (2017, 20 d'octubre). Contra l'escola arreu dels Països Catalans: I'obsessió de Ciutadans i el PP. VilaWeb. https://www.vilaweb.cat/noticies/contra-lescola-arreu-dels-paisos-catalans-lobsessiode-ciutadans-i-el-pp-analisi-aravot/

INE. (2020). Mujeres investigadoras por sectores de ejecución. 6.3 Mujeres investigadoras por sectores de ejecución.

https://www.ine.es/ss/Satellite?c=INESeccion_C\&cid=1259925528337\&p=1254735110672\&pagename =ProductosYServicios\%2FPYSLayout\&param1=PYSDetalle\&param3=1259924822888

Informe Eurydice. (2015/2020). https://eacea.ec.europa.eu/national-policies/eurydice

Lasagabaster, I. (2013). Reflexiones sobre la universidad, su crisis, la educación y la crisis económica. Revista catalana de dret públic, 47, 21-39.

Malagón Plata, L. A. (2009a). La pertenencia curricular: un estudio en tres programas universitarios. Educación y Educadores, 12(1), 11-27. http://www.scielo.org.co/pdf/eded/v12n1/v12n1a03.pdf

Malagón Plata, L. A. (2009b). La relación universidad-sociedad: una visión crítica. Revista Perspectivas Educativas, 2, 17-50. http://revistas.ut.edu.co/index.php/perspectivasedu/article/viewFile/787/615

Martínez García, J. S. (2007). Clase social, género y desigualdad de oportunidades educativas. Revista de educación, 342, 287-306.

Musselin, C. (2013). Redefinition of the relationships between academics and their university. Higher Education, 65, 25-37. https://doi.org/10.1007/s10734-012-9579-3

Obiol, S., i Villar, A. (2016). Locas por la ciencia. Las dificultades de rendir cuentas y cuidar. Revista Mètode, 92, 37-42. https://metode.es/revistas-metode/document-revistes/locas-por-ciencia.html

Pastor, I. (2017). La desigualtat de gènere també està present a les universitats [Conferència]. Igualada: Campus Terres de l'Ebre - Universitat Roviri i Virgili. https://diaridigital.urv.cat/la-desigualtat-de-genere-tambeesta-present-a-les-universitats

Proyecto Tuning (2008). Tuning educational structures in Europe. La contribución de las universidades al proceso de Bolonia. http://www.deusto-publicaciones.es/deusto/index.php/es/tuning-es/tuning-educational-es

Reyes-Lara, D. (2015). La universidad intervenida: las nuevas técnicas del poder y el biomárquetin. Revista Oxímora, 6, 46-64.

Ritzer, G. (1996). La Mcdonalización de la sociedad. Ariel.

Rubio, M. (2021, 17 de gener). La universitat suspèn en igualtat de gènere. Públic. https://www.publico.es/public/universitat-suspen-igualtat-genere.html

Sábato, E. (2021). La resistencia. Seix Barral-Planeta.

Samper, LI. (1998). Las desigualdades en el currículum de Ciencias Sociales. A: Los valores y la Didáctica en Ciencias Sociales: Actas del IX Simposium de Didáctica de las Ciencias Sociales (p. 69-74). Universitat de Lleida. 
Sancho, J. M., Ornellas, A., i Arrazola, J. (2018). La situación cambiante de la universidad en la era digital. RIED: Revista Iberoamericana de Educación a Distancia, 21(2), 31-49. https://doi.org/10.5944/ried.21.2.20673

Slaughter, S., i Rhoades, G. (2004). Academic capitalism and the new economy: markets, state, and higher education. The Johns Hopkins University Press.

Taberner, J. (1999). Sociología y educación: funciones del sistema educativo en sociedades modernas. Tecnos. 